удК 331.556 .4

\title{
ТРУДОВА МІГРАЦІЯ В ЄВРОПІ ТА ІІЇ ВПЛИВ НА УКРАЇНУ
}

\section{LABOUR MIGRATION IN EUROPE AND ITS IMPACT ON UKRAINE}

\author{
Ливдар Марта Василівна \\ кандидат економічних наук, доцент, \\ Національний університет «Львівська політехніка» \\ ORCID: https://orcid.org/0000-0003-1925-7781 \\ Федевич Людмила Станіславівна \\ кандидат економічних наук, доцент, \\ Національний університет «Львівська політехніка» \\ ORCID: https://orcid.org/0000-0002-3097-7467

\section{Буковська Наталія Юріївна} \\ студентка, \\ Національний університет «Львівська політехніка» \\ ORCID: https://orcid.org/0000-0001-6406-9574
}

\section{Lyvdar Marta, Fedevych Liudmyla, Bukovska Nataliia National University "Lviv Polytechnic"}

\begin{abstract}
У статті визначено, що Україна є одним із лідерів за кількістю працездатного населення, що працює не на батьківщині. Масова еміграція грає значну роль в Україні, оскільки кількість трудових мігрантів оцінюється у 2-3 мільйони. Здійснено аналіз основних причин міграції з України та масової міграції в Європу. Виокремлено, основні проблеми, які постають перед країнами внаслідок міграційного процесу та визначення впливу міграції на економіку країни в цілому. Грошові перекази покращують добробут сімей мігрантів та стимулюють внутрішній попит; у поточній економічній кризі це є одним з джерел валютних надходжень для країни. Проте еміграція зменшує пропозицію робочої сили на українському ринку праці, що в кінцевому результаті призводить до втрати кваліфрікації. Оцінено розмір заробітних плат по регіонах України та відповідність сальдо міграції. Авторами досліджено динаміку міграційного руху та шляхи нелегального виїзду за кордон і наслідки від цього.

Ключові слова: міграція, міжнародна інтеграція, сальдо міграції, середня заробітна плата, трудова міграція.
\end{abstract}

В статье определено, что Украина является одним из лидеров по количеству трудоспособного населения, работает не на родине. Массовая эмиграция играет значительную роль в Украине, поскольку количество трудовых мигрантов оценивается в 2-3 миллиона. Осуществлен анализ основных причин миграции из Украины и массовой миграции в Европу. Выделены основные проблемы, возникающие перед странами вследствие миграционного процесса и определения влияния миграции на экономики страны в целом. Денежные переводы улучшают благосостояние семей мигрантов и стимулируют внутренний спрос; в текущей экономической кризисе это является одним из источников валютных поступлений для страны. Однако эмиграция умешает предложение рабочей силы на украинском рынке труда, что в конечном итоге приводит к потере квалификации. Оценен размер заработных плат по регионам Украины и соответствие сальдо миграции. Авторами исследована динамика миграционного движения и пути нелегального выезда за границу и последствия от этого.

Ключевые слова: миграция, международная интеграция, сальдо миграции, средняя заработная плата, трудовая миграция.

The article states that Ukraine is one of the leaders in the number of able-bodied people working abroad. Mass emigration plays a significant role in Ukraine, as the number of migrant workers is estimated at 2-3 million. The main causes of migration from Ukraine and mass migration to Europe are analysed, namely: the development of migration processes in Ukraine is influenced by many factors, including the annexation of Crimea and the conflict in eastern Ukraine, which have led to the economic crisis in the country. The introduction of a visa-free regime with the European Union has also increased the outflow of the population from Ukraine. It should be noted that Ukraine's significant 
welfare lag behind neighbouring countries in the medium term will continue, which will also affect the departure of the working population. These and other factors are favourable for external migration. The destination countries for labour migrants from Ukraine are primarily neighbouring countries (Russia, Poland, the Czech Republic), as well as the countries of Southern Europe (Italy, Spain, Portugal). The impact of migration on Ukraine leads to the loss of part of the labour and intellectual potential and, accordingly, may become a factor inhibiting economic development. The main problems facing the countries as a result of the migration process and determining the impact of migration on the economy as a whole are singled out. It is noted that in countries with negative net migration rate, namely Austria, Spain, Germany, Hungary and the Czech Republic, the reasons for such migration can be both personal and political opinions, but then negative values will only increase, as the above countries other than Spain have refused to sign the Global Compact for Migration, so these countries want to end the refugee asylum policy. Remittances improve the well-being of migrants' families and stimulate domestic demand; in the current economic crisis, this is one of the sources of foreign exchange earnings for the country. However, emigration reduces the labour supply in the Ukrainian labour market, which ultimately leads to loss of skilled specialists. Currently, there is a shortage of workers in almost all types of activity, especially in construction (this was reported by half of the surveyed construction companies) and industry. The size of wages by regions of Ukraine and the correspondence of the net migration rate are estimated. The authors study the dynamics of migration, ways of illegal departure abroad, and the consequences of this.

Keywords: migration, international integration, net migration rate, average wages, labour migration.

Постановка проблеми. Трудова міграція характеризується швидкою мобільністю і невибагливістю до умов праці, таким чином це задовольняє потреби робочого ринку. Місцем, куди найбільше подорожують у пошуках роботи, або так званим епіцентром робочої сили $\epsilon$ Європа. Проте не тільки українці шукають кращого життя, але й багато людей в Європі змінюють своє місце проживання на іншу країну, сподіваючись реалізувати себе там. Міграція населення 3 однієї країни в іншу, зумовлює дисбаланс між розподілом населення, таким чином в світі виникає демографрічна криза.

Аналіз останніх досліджень і публікацій. Розвиток і проблеми трудової міграції досліджують багато авторів. Іноземні вчені Дж. Борхас, С. Брю, П. Кругман, Я. Мінсер, А. Рой у своїх працях відобразили проблеми управління імміграційними потоками. Дж. Перкінз, Г. Грубел, А. Скотт, М. Бейн, О. Старк займалися вивченням економічного ефректу трудової міграції. Міграцію робочої сили досліджували наступні українські економісти Е. Лібанова, О. Малиновська, Н. Марченко, А. Мокій, У. Садова, О. Хомра, В. Шевчук та інші. Проте це питання ще не до кінця вивчене і потребує подальшого дослідження та вирішення проблем.

Формулювання цілей статті. Метою та завданням статті $€$ дослідження трудової міграції в Європі, виділення основних проблем та перспектив вирішення проблем, які постають перед країнами внаслідок міграційного процесу, визначення впливу міграції на економіку країни та її діяльність в цілому.

Виклад основного матеріалу. Трудова міграція є однією з основних проблем розвитку економіки та країни в цілому. Трудова міграція тісно пов'язана з міжнародною інтеграцією і виділяють такі її наступні етапи.

\begin{tabular}{|c|c|}
\hline Перший етап & $\begin{array}{c}\text { Укладення } \\
\text { преференційних } \\
\text { торговельних угод }\end{array}$ \\
\hline Другий етап & Зона вільної торгівлі \\
\hline Третій етап & Митний союз \\
\hline Четвертий етап & Спільний ринок \\
\hline П'ятий етап & Економічний союз \\
\hline
\end{tabular}

Рис. 1. Етапи міжнародної інтеграції

Джерело: складене авторами на основі [1, с. 21-24]

Перший етап - укладання префреренційних торговельних відносин - коли певна кількість країн, що мають намір інтегруватися зменшують взаємні тарисри, але зберігають рівень тарифрів для інших країн. Прикладом є ЄВАТ та Україна, яка вступила в ці відносини 1 червня 2012 року. Були підписані двосторонні угоди про торгівлю сільськогосподарською продукцією, торгівля послугами та інше. Другий етап зона вільної торгівлі з ЄС почала діяти 31 січня 2016 року, що відкриває можливості для українського бізнесу вийти за рамки внутрішнього ринку і охопити 50788 млн. чоловік. Третій етап - створення митного союзу, прикладом може стати союз між Туреччиною та ЄС. Україна в 2017 році, мала на меті вступити в подібний союз, проте в 2020 році, було прийнято рішення, що це буде не вигідно для нашої країни, оскільки дана угода не дає митного союзі 3 країнами, що мають дану угоду з ЄС. Четвертий етап - спільний ринок - забезпечення вільного руху товарів, послуг та робочої сили. В Україні таким прикладом $€$ введення безвізового режиму між Україною та ЄС. П'ятий етап створення економічного союзу полягає у змінні більш глобальних сорер життя, так даний союз потребує забезпечення запровадження єдиної валюти, що діє в Європі [1, с. 21-24]. 
Проаналізувавши всі етапи інтеграції України 3 Європою та іншими країнами, можна зробити висновок, що із наближенням до Європи, все більше наших громадян мігрує за кордон. Проте причини такої міграції $€$ досить різними. В різних областях України різні значення міграцій, яке представлено в таблиці 1.

В Україні протягом досліджуваного періоду кількість мігрантів збільшувалося. Щодо Вінницької області, то у 2016-2019 роках обсяги мігрантів значно зменшилася і у 2019 році -2724 осіб. У Волинській область кількість мігрантів незначна, а 3 2011-2014 роки почала збільшуватися, проте з 2015-2019 роки відбувався спад. В Дніпропетровській області 3 2010-2012 роки відбулося збільшення мігрантів, але з 2012-2019 роки спостерігаємо спад, проте у 2017 році бачимо значне збільшення мігрантів. Щодо Донецької, Луганської, області, то до 2014 року там була нормальна ситуація 3 міграцією, так у 2014 році по 2019 рік бачимо значний відтік людей це пов'язано з військовими діями на даній території. В Житомирській області з 2013-2019 роки міграційний приріст від'ємний. Закарпатська і Рівненська область характеризуються від'ємним сальдо міграції протягом усього досліджуваного періоду. В Івано-Франківській область 2015 і 2017 роки спостерігаємо позитивне сальдо мігрантів, а в 2016, 2018-2019 роки навпаки. В Київські, Львівській, Одеській, Харківській області та місті Києві спостерігаємо додатне сальдо протягом 2011-2019 років. В Кіровоградській, Рівненській, Сумській та Чернігівській областях спостерігається від'ємне сальдо міграції протягом 2014-2019 років. Миколаївська, Полтавська, Тернопільська області характеризуються від'ємним сальдо міграції з 2016 по 2019 роки. Хмельницька і Черкаська область має таке ж сальдо з 2015 по 2019 роки.

Дослідивши міграційний процес в областях України, встановлено, що він $€$ не пропорцій-

Міграційний рух населення у 2011-2019 році (осіб)

Таблиця 1

\begin{tabular}{|c|c|c|c|c|c|c|c|c|c|}
\hline \multirow{2}{*}{ Назва регіонів } & \multicolumn{9}{|c|}{ Роки } \\
\hline & 2011 & 2012 & 2013 & 2014 & 2015 & 2016 & 2017 & 2018 & 2019 \\
\hline Україна & 3054 & 3377 & 3619 & 4012 & 5230 & 6475 & 8777 & 10573 & 12264 \\
\hline Зінницька & 2396 & 2694 & 2956 & 3244 & 4214 & 5153 & 7613 & 9255 & 10661 \\
\hline Волинська & 2292 & 2591 & 2817 & 3161 & 4237 & 5151 & 7249 & 8868 & 10333 \\
\hline Дніпропетровська & 3064 & 3385 & 3544 & 4021 & 4996 & 5913 & 8247 & 10188 & 12084 \\
\hline Донецька & 3439 & 3811 & 4117 & 4498 & 5830 & 7111 & 9886 & 11298 & 13177 \\
\hline Житомирська & 2399 & 2617 & 2848 & 3180 & 4091 & 4997 & 7207 & 8624 & 9832 \\
\hline Закар & 2499 & 2695 & 2906 & 3353 & 4535 & 5597 & 8127 & 9946 & 11005 \\
\hline Запорізька & 2954 & 3155 & 3434 & 4048 & 4998 & 6125 & 8305 & 10435 & 12249 \\
\hline Івано-Франкі & 2461 & 2682 & 2876 & 3138 & 4191 & 4993 & 6935 & 8334 & 9625 \\
\hline Київська & 3245 & 3528 & 3624 & 4100 & 5489 & 6406 & 8719 & 11146 & 13259 \\
\hline Kipo: & 2414 & 2660 & 2918 & 3088 & 4149 & 4927 & 6798 & 8190 & 9450 \\
\hline Луга & 3346 & 3335 & 3657 & 3638 & 4250 & 6009 & 7484 & 8731 & 10195 \\
\hline Львівська & 2533 & 2791 & 3029 & 3353 & 4643 & 5623 & 7879 & 9172 & 10415 \\
\hline Миколаївс & 2848 & 3321 & 3641 & 4143 & 5227 & 6448 & 8828 & 10197 & 12833 \\
\hline Оде & 2822 & 3100 & 3440 & 3685 & 5154 & 6535 & 8297 & 9564 & 11103 \\
\hline Полтавська & 2911 & 3215 & 3350 & 3653 & 4624 & 5673 & 7839 & 10003 & 10906 \\
\hline Рівненська & 2693 & 2903 & 3285 & 3665 & 4755 & 5703 & 7676 & 9558 & 11552 \\
\hline Сумська & 2474 & 2722 & 2954 & 3284 & 4217 & 5129 & 7359 & 8454 & 9701 \\
\hline Tepн & 2132 & 2466 & 2697 & 2992 & 3951 & 4781 & 6828 & 8307 & 9651 \\
\hline Харківс & 2798 & 3068 & 3250 & 3598 & 4653 & 5499 & 7447 & 9072 & 10410 \\
\hline Херсонська & 2274 & 2543 & 2811 & 3043 & 4155 & 5259 & 7206 & 8495 & 9828 \\
\hline Хмельницька & 2390 & 2728 & 3030 & 3418 & 4326 & 5315 & 7559 & 8976 & 10844 \\
\hline Черк & 2479 & 2726 & 2940 & 3151 & 4243 & 5089 & 7267 & 8628 & 10008 \\
\hline Чернівецька & 2320 & 2628 & 2862 & 3000 & 4061 & 5058 & 7265 & 9025 & 9608 \\
\hline Чернігівська & 2211 & 2498 & 2703 & 2924 & 3924 & 4804 & 6656 & 8005 & 8851 \\
\hline и. Київ & 4819 & 5368 & 5618 & 6414 & 8486 & 11094 & 14035 & 16546 & 18869 \\
\hline
\end{tabular}

Джерело: складено авторами на основі джерела [2] 
ним. Тому для детального аналізу міграційних процесів порівняємо середні розміри заробітних плат по регіонах.

Найбільші заробітні плати за весь досліджуваний період спостерігаються в Дніпропетровській, Донецькій, Запорізькій, Київській, Миколаївській, Одеській областях та місті Києві. Позитивне сальдо міграції та і великий розмір заробітних плат характерний для Київської, Львівської, Одеської, Полтавської та Харківської областей. Малий розмір заробітної платі та від'ємне сальдо міграції в Вінницькій, Волинській, Івано-Франківській, Кіровоградській, Луганській, Сумській, Тернопільській, Херсонській, Хмельницькій та Черкаській областях. Велика заробітна плата, але від'ємне сальдо міграції спостерігається в Дніпропетровській, Донецькій, Закарпатській, Запорізькій, Миколаївській та Рівненській областях.

Отже, внаслідок малих заробітних плат та нестабільної економічної ситуація в Україні протягом усього часу їі незалежності виникло від'ємне сальдо міграції у Вінницькій, Волинській, Івано-Франківській, Кіровоградській, Луганській, Сумській, Тернопільській, Херсонській, Хмельницькій та Черкаській областях. Щодо від'ємного сальда на Сході України, то це пов'язано з військовими діями, які тривають протягом 6 років, це призвело до вимушеного переселення громадян на інші території, як наслідок, велика частина виїхали за кордон, особливо чоловіки, які не хотіли вступати на військову службу, але це стосується не тільки громадян, які жили на окупованих територіях, але й на усіх інших. Позитивне значення сальда міграції та великі розміри заробітної плати зафріксовані в Київській, Львівській, Одеській, Полтавській, Харківській областях, куди приїжджають на роботу громадяни у пошуках «кращої» роботи та життя.

Найбільша кількість мігрантів усього по території була у 2010-2014 роки. Так у Європі найбільше значення міграційного приросту спо-

Середній розмір заробітної плати по регіонах у 2011-2019 роках (грн.)

\begin{tabular}{|l|c|c|c|c|c|c|c|c|c|}
\hline \multirow{2}{*}{ Назва регіонів } & \multicolumn{9}{|c|}{ Роки } \\
\cline { 2 - 10 } & $\mathbf{2 0 1 1}$ & $\mathbf{2 0 1 2}$ & $\mathbf{2 0 1 3}$ & $\mathbf{2 0 1 4}$ & $\mathbf{2 0 1 5}$ & $\mathbf{2 0 1 6}$ & $\mathbf{2 0 1 7}$ & $\mathbf{2 0 1 8}$ & $\mathbf{2 0 1 9}$ \\
\hline Україна & 3054 & 3377 & 3619 & 4012 & 5230 & 6475 & 8777 & 10573 & 12264 \\
\hline Вінницька & 2396 & 2694 & 2956 & 3244 & 4214 & 5153 & 7613 & 9255 & 10661 \\
\hline Волинська & 2292 & 2591 & 2817 & 3161 & 4237 & 5151 & 7249 & 8868 & 10333 \\
\hline Дніпропетровська & 3064 & 3385 & 3544 & 4021 & 4996 & 5913 & 8247 & 10188 & 12084 \\
\hline Донецька & 3439 & 3811 & 4117 & 4498 & 5830 & 7111 & 9886 & 11298 & 13177 \\
\hline Житомирська & 2399 & 2617 & 2848 & 3180 & 4091 & 4997 & 7207 & 8624 & 9832 \\
\hline Закарпатська & 2499 & 2695 & 2906 & 3353 & 4535 & 5597 & 8127 & 9946 & 11005 \\
\hline Запорізька & 2954 & 3155 & 3434 & 4048 & 4998 & 6125 & 8305 & 10435 & 12249 \\
\hline Івано-Франківська & 2461 & 2682 & 2876 & 3138 & 4191 & 4993 & 6935 & 8334 & 9625 \\
\hline Київська & 3245 & 3528 & 3624 & 4100 & 5489 & 6406 & 8719 & 11146 & 13259 \\
\hline Кіровоградська & 2414 & 2660 & 2918 & 3088 & 4149 & 4927 & 6798 & 8190 & 9450 \\
\hline Луганська & 3346 & 3335 & 3657 & 3638 & 4250 & 6009 & 7484 & 8731 & 10195 \\
\hline Львівська & 2533 & 2791 & 3029 & 3353 & 4643 & 5623 & 7879 & 9172 & 10415 \\
\hline Миколаївська & 2848 & 3321 & 3641 & 4143 & 5227 & 6448 & 8828 & 10197 & 12833 \\
\hline Одеська & 2822 & 3100 & 3440 & 3685 & 5154 & 6535 & 8297 & 9564 & 11103 \\
\hline Полтавська & 2911 & 3215 & 3350 & 3653 & 4624 & 5673 & 7839 & 10003 & 10906 \\
\hline Рівненська & 2693 & 2903 & 3285 & 3665 & 4755 & 5703 & 7676 & 9558 & 11552 \\
\hline Сумська & 2474 & 2722 & 2954 & 3284 & 4217 & 5129 & 7359 & 8454 & 9701 \\
\hline Тернопільська & 2132 & 2466 & 2697 & 2992 & 3951 & 4781 & 6828 & 8307 & 9651 \\
\hline Харківська & 2798 & 3068 & 3250 & 3598 & 4653 & 5499 & 7447 & 9072 & 10410 \\
\hline Херсонська & 2274 & 2543 & 2811 & 3043 & 4155 & 5259 & 7206 & 8495 & 9828 \\
\hline Хмельницка & 2390 & 2728 & 3030 & 3418 & 4326 & 5315 & 7559 & 8976 & 10844 \\
\hline Черкаська & 2479 & 2726 & 2940 & 3151 & 4243 & 5089 & 7267 & 8628 & 10008 \\
\hline Чернівецька & 2320 & 2628 & 2862 & 3000 & 4061 & 5058 & 7265 & 9025 & 9608 \\
\hline Чернігівська & 2211 & 2498 & 2703 & 2924 & 3924 & 4804 & 6656 & 8005 & 8851 \\
\hline м. Київ & 4819 & 5368 & 5618 & 6414 & 8486 & 11094 & 14035 & 16546 & 18869 \\
\hline
\end{tabular}

Таблиця 2 
стерігається у 2010-2014 роках. Щодо країн, де міграційний приріст від'ємний, то це Австрія, Іспанія, Республіка Німеччина, Угорщина та Чехія, причинами такого міграційного стану можуть бути як особисті погляди громадян, так і політичні, проте далі це від'ємне значення буде тільки збільшуватися, оскільки вище перераховані країни окрім Іспанії відмовилися від підписання пакту ООН про міграцію, таким чином дані країни хочуть припинити політику притулку біженців. Як результат, відбувається зниження мігрантів в Європу в 2016-2018 роках, оскільки відбулося закриття «балканського маршруту» яким нелегально заїжджали в ЄС контрабанди людей. Проте після цього мігранти розробили Східний Середземноморський маршрут, який проходить через Туреччину - Егейське море - Грецію тому зрозуміло, чому таке велике додатне сальдо в даній країні. Також $€$ Центральний Середземноморський Маршрут, що проходить через Лівію / Туніс - Італію, де $є$ велика додатнє сальдо. Саме тому Італія

Таблиця 3

Кількість міждержавних мігрантів за країнами в'їзду (виїзду) у 2010-2018 роках (осіб)

\begin{tabular}{|c|c|c|c|c|c|c|c|c|c|}
\hline \multirow{2}{*}{ Територія } & \multicolumn{9}{|c|}{ Міграційний приріст, скорочення (-) } \\
\hline & 2010 & 2011 & 2012 & 2013 & 2014 & 2015 & 2016 & 2017 & 2018 \\
\hline Усього & 16133 & 17096 & 61844 & 31913 & 21099 & 9250 & 7846 & 8126 & 15055 \\
\hline \multicolumn{10}{|l|}{ у тому числі } \\
\hline Країн Європи & 9531 & 11212 & 17067 & 12814 & 11808 & 6061 & 2562 & 2451 & 573 \\
\hline \multicolumn{10}{|l|}{3 них } \\
\hline Австрія & -99 & -122 & -60 & -62 & -116 & -106 & -48 & -86 & -177 \\
\hline Білорусь & 326 & 523 & 1266 & 853 & 296 & 124 & 253 & 406 & 333 \\
\hline Естонія & 35 & 19 & 43 & 47 & 20 & 20 & 17 & 16 & 6 \\
\hline Іспанія & -237 & -201 & -131 & -57 & 71 & -4 & 15 & -7 & -99 \\
\hline Італія & -34 & -6 & 184 & 159 & 74 & 133 & 60 & 161 & 187 \\
\hline Латвія & 132 & 147 & 176 & 139 & 50 & 60 & 30 & 53 & 187 \\
\hline Литва & 80 & 86 & 115 & 70 & 10 & -9 & 10 & -113 & 39 \\
\hline Молдова & 3317 & 3157 & 3655 & 2733 & 2005 & 864 & 340 & 528 & -337 \\
\hline Республіка Німеччина & -1426 & -1374 & -957 & -1114 & -1037 & -1146 & -355 & -891 & 1084 \\
\hline Польща & 5 & 64 & 1137 & 363 & -30 & 79 & -3 & -36 & -1821 \\
\hline Російська Федерація & 7986 & 9145 & 11081 & 9897 & 11276 & 7377 & 2443 & 2426 & -97 \\
\hline Угорщина & -91 & -124 & -183 & -314 & -766 & -1344 & -348 & -259 & 1845 \\
\hline Чехія & -621 & -368 & -303 & -365 & -137 & -102 & -50 & -89 & -285 \\
\hline Країн Америки & -255 & -316 & 1342 & 657 & -678 & -762 & -631 & -1093 & -253 \\
\hline \multicolumn{10}{|l|}{3 них } \\
\hline Канада & -63 & -7 & 114 & 11 & -10 & 17 & 18 & 5 & -2253 \\
\hline США & -238 & -344 & 912 & 470 & -786 & -848 & -701 & -1218 & -4 \\
\hline Країн Азії & 6598 & 6016 & 35741 & 15119 & 7850 & 1979 & 3973 & 4624 & -2386 \\
\hline \multicolumn{10}{|l|}{$3 \mathrm{Hиx}$} \\
\hline Азербайджан & 976 & 1113 & 3328 & 2027 & 1673 & 912 & 640 & 464 & 908 \\
\hline Вірменія & 1050 & 982 & 1130 & 891 & 769 & 598 & 232 & 418 & 403 \\
\hline Грузія & 1069 & 930 & 1664 & 1062 & 730 & 699 & 373 & 448 & 434 \\
\hline Ізраїль & -674 & -733 & -15 & -175 & -625 & -1979 & -851 & 47 & 467 \\
\hline Казахстан & 330 & 401 & 581 & 462 & 191 & -41 & 32 & -32 & -22 \\
\hline Киргизстан & 129 & 162 & 200 & 121 & 68 & 56 & 41 & 58 & 53 \\
\hline Таджикистан & 170 & 182 & 470 & 313 & 92 & 76 & 67 & 64 & 103 \\
\hline Туреччина & 295 & 189 & 1962 & 1049 & 303 & 260 & 380 & 1053 & 1483 \\
\hline Туркменістан & 164 & 157 & 7828 & 2314 & 765 & -1117 & 243 & -2207 & 478 \\
\hline Узбекистан & 1877 & 1708 & 2646 & 2653 & 837 & 329 & 365 & 671 & 60 \\
\hline Країн Афррики & 257 & 175 & 7681 & 3302 & 2126 & 1971 & 1941 & 2130 & 4475 \\
\hline Країн Австралії та Океанії & 2 & 8 & 13 & 21 & -7 & 1 & 1 & 14 & -6 \\
\hline
\end{tabular}

Джерело: складено авторами на основі джерела [4] 
з 2010 року не приймає закон «Decreto Flussi» тобто дозвіл на отримання документів мігрантам на роботу і проживання, проте можна отримати такі документи, якщо біженець і на посезонні роботи. Західний Середземноморський маршрут пролягає через Мароко/ Алжир - Іспанія. Через такі нелегальні перетинання кордону, багато людей зникли безвісти і потонули в Середземному морі [5]. Щодо країн Асррики, то позитивне сальдо міграції може бути зумовлене переселенцями з Сирії, Ірану.

Висновки. Населення України протягом усього досліджуваного періоду мігрувало в пошуках кращого життя, вищих заробітних плат та достойного майбутнього. Наслідком чого було зменшення чисельності населення, народжуваності і старіння нації. Такий рух населення має значний вплив на українську економіку, приносячи як вигоди, так і витрати. Зокрема, грошові перекази покращують добробут сімей мігрантів та стимулюють внутрішній попит та є одним з основних джерел валютних надходжень для країни. Протягом 2020 року українські трудові переказали 3-за кордону додому 8,5 мільярдів доларів. Незважаючи на коронавірус та весняному карантину заробітчани надсилають на батьківщину майже стільки ж грошей, як у 2019 [6].
Проте на сьогодні багато країн роблять усе, для того щоб уникнути заселення біженцями, людей, які нелегально проживають на території держави. Але проблема міграції завжди буде важливою, оскільки кожна людина має право вибору, чи залишатися в своїй державі, чи їхати в пошуках кращого життя за кордон. Після підписання Шенгенської угоди безліч українці виїхали і шляхом обману залишилися там жити, або періодично їздять на заробітки і приїжджаючи в Україну живуть за гроші зароблені там, і це повторяється безліч разів. Та з легкістю можна сказати, що у всіх країнах відбувається відтік кадрів за кордон, і державі потрібно шукати хороших спеціалістів серед іноземців. То чому б не дати хорошу роботу тут, в Україні, враховуючи те, що зарплати є достатніми? Тому політика щодо використання позитивних наслідків трудової еміграції та мінімізації її вад дуже актуальна для України. Така політика може бути зосереджена на сорерах зайнятості, соціальній та податковій політиці та покращенні ділового середовища.

Особливо говорячи про ситуацію, що склалася зараз у світі, коли ми переживаємо час пандемії, напевно кожен зрозумів, що важливо бути «вдома». Відбулися кардинальні зміни, оскільки майже всі Українці повернулися додому із «заробітків».

\section{СПИСОК ВИКОРИСТАНИХ ДЖЕРЕЛ:}

1. Кваша С.М., Файчук О.М., Файчук О.В. Європейська економічна інтеграція : навчальний посібник. Київ : Видавничий центр НУБіп України, 2019. С. 21-24.

2. Міграційний рух населення України. Архів за 2019 рік. Державна служба статистики України. URL: http://www.ukrstat.gov.ua/operativ/operativ2019/ds/mr/mr_u/arh_mr2019_u.html

3. Середня зарплата в Україні 2020 p. URL: https://index.minfin.com.ua/ua/labour/salary/average/2020/

4. Міграційні процеси в світі. Державна служба статистики України. URL: http://database.ukrcensus.gov.ua/ PXWEB2007/.

5. УHIAH. URL: https://www.unian.ua/world/2326951-2017-roku-kilkist-migrantiv-yaki-namagalisya-distatisyaevropi-cherez-seredzemne-more-zmenshilas-udvichi-oon.html

6. Radiosvoboda. URL: https://www.radiosvoboda.org/a/trudova-migratsiya/30937742.html

\section{REFERENCES:}

1. Kvasha S.M., Fajchuk O.M., \& Fajchuk O.V. (2019) Jevropejsjka ekonomichna integhracija: navchaljnyj posibnyk [European economic integration]. Kyiv: Vydavnychyj centr NUBiP Ukrajiny, pp. 21-24.

2. Mihratsiinyi rukh naselennia Ukrainy. Arkhiv za 2019 rik. Derzhavna sluzhba statystyky Ukrainy [Migration movement of the population of Ukraine. Archive for 2019. State Statistics Service of Ukraine]. Available at: http://www.ukrstat.gov.ua/operativ/operativ2019/ds/mr/mr_u/arh_mr2019_u.html

3. Serednia zarplata v Ukraini $2020 \mathrm{r}$. [The average salary in Ukraine in 2020]. Available at: https://index.minfin.com.ua/ ua/labour/salary/average/2020/

4. Mihratsiini protsesm $v$ sviti. Derzhavna sluzhba statystyky Ukrainy [Migration process in the world. State Statistics Service of Ukraine]. Available at: http://database.ukrcensus.gov.ua/PXWEB2007/

5. UNIAN. Available at: https://www.unian.ua/world/2326951-2017-roku-kilkist-migrantiv-yaki-namagalisyadistatisya-evropi-cherez-seredzemne-more-zmenshilas-udvichi-oon.html

6. Radiosvoboda. Available at: https://www.radiosvoboda.org/a/trudova-migratsiya/30937742.html 